\title{
Contextualisation of the Information Literacy Environment in the South African Education Sector
}

\author{
Oluwole O. Durodolu ${ }^{1,2}$ and ${ }^{1}$ Samuel Maredi Mojapelo \\ ${ }^{1}$ University of South Africa, Pretoria, South Africa \\ ${ }^{2}$ University of Lagos Library, Akoka, Lagos, Nigeria \\ woledurodolu@gmail.com \\ mojapsm@unisa.ac.za \\ DOI: 10.34190/EJEL.20.18.1.005
}

\begin{abstract}
This study embarked on an in-depth content analysis of the information literacy environment in the South African education sector. The review of literature encompasses a comprehensive critical analysis of available appropriate and contemporary literature, which further expounds the research problem. This research adopted the qualitative method of data collection; hence, policy documents, conference proceedings and journal articles about the subject matter were analytically evaluated to identify whether there is a research gap that may have remained unanswered in previous studies. The study emphasises various ICT tools and techniques that will promote e-learning in South African educational sector; this was done in recognition of its essential role. South Africa struggles with challenges associated with the digital divide, a result of the inability of many to access ICT tools capable of enhancing their performance, particularly in a racially divided country such as South Africa, where a separate educational development policy was pursued during the apartheid era, in favour of the white minority. The trends in information literacy and essential issues regarding information literacy skills in South Africa are highlighted. The challenges associated with information literacy in South Africa are presented, and different opportunities in information literacy are also discussed. The paper concludes with the gaps and options in information literacy in South Africa. Finally, this paper offers a comprehensive review of the information literacy development in the South African education sector, which constitutes an essential perspective in the understanding of the global information literacy development.
\end{abstract}

Keywords: Information literacy, ICT4D, information access, contextualisation, education sector.

\section{Introduction}

This study focuses on the concept of information literacy as it influences teaching, learning and development in South Africa. In this paper, the status of information literacy is discussed, revealing the extent, condition and present situation. The trends in information literacy, which reflects the direction and essential issues in information literacy in South Africa, are highlighted, coupled with the challenges and opportunities associated with information literacy. Different perspectives in education are presented. This article also focuses on the cost of internet access, its speed or delays, the level of information and communication technology (ICT) infrastructure and electricity generation, as some of the significant challenges affecting the growth of information access. Various intervention programmes, initiated by corporate organisations in relation to information literacy, are also mentioned. These organisations are the Molteno Institute of Language and Literacy (MILL), Trydian Interactive and Chevron Interventions. It must be noted that modern teaching requires the ability to find, evaluate, organise and communicate information, and the awareness that information is in a state of continuous flux, which means that it changes as quickly as it is available. Teachers, in the view of Solomon, Wilson and Taylor (2012, p.4), are expected to continuously expand their knowledge to be successful in and up to date, and this ability requires information literacy. In South Africa, owing to the legacy of the apartheid, before 1994, there was inadequate allocation and provision of school and public libraries, particularly in the disadvantaged rural communities. Consequently, information literacy levels of most teachers and learners are low. Furthermore, learners' outcomes are low because they lack information literacy skills to find information to boost their academic achievements.

Many contemporary researchers have commented on the concept of information literacy, for instance, Durodolu $(2019$, p.4), who sees information literacy as a necessary requirement to survive the predicament brought about as a result of information overload, and affirmed that to moderate this difficulty, it is vital to gain skills that will enable people to recognise reliable sources of information on the internet or any e-learning platform- particularly by educators whose roles and obligation it is to increase the boundaries of knowledge. Association of College and Research Libraries (ACRL) (2016) perceived Information literacy as a combined 
ability covering the insightful discovery of information, the awareness of how information is created and valued, and the use of information in forming new knowledge and partaking ethically in communities of learning. (ACRL, 2016, p.4). In the same vein, Chartered Institute of Library and Information Professionals (CILIP, 2018, p.3) defined Information literacy as the capacity to reason critically and make valued judgements about acquired information. This definition implies that knowledge of information literacy enables citizens to display knowledgeable views and opinion that empower them to engage in activities that makes them responsible citizens.

The Scottish Information Literacy Project (2013) describes information literacy as the panacea for stimulating problem-solving abilities, particularly those problems attributed to the modern use of technology that drives information access. It maintains that information literacy assists scholars with critical thinking skills, to seek answers to important questions, to seek information from various sources, form intellectual opinions and evaluate sources of information for informed judgment the ability to seek answers to critical questions, find information from various sources, form intelligent opinions and evaluate sources of information for informed judgement necessary for decision making. Another area where information literacy is crucial is in the field of elearning, which is a new concept that encourages the use of electronic technologies in accessing educational courses outside the physical classroom environment, in some cases, educational delivery is done via online arrangement (Banciu, Petre and Boncea, 2019, p.465). Even though it is convenient and flexible to use elearning platforms, the effective use of it requires information literacy. In this study, e-learning is synonymously used to refer to the application of ICT tools and techniques to promote learning.

\section{South African context}

South Africa's Bill of Rights is unwavering in the ambition that all citizens should have the right to basic education, including adult basic education and further education. This is in recognition of the fact that education and skills development holds the key to the future prosperity of South Africa. Given this, the government, at all levels, gives special attention to education and skills development. To demonstrate its seriousness about this undertaking, the government spends a considerable part of its budget on education. In the 2012-13 fiscal year, for example, education constituted more than $21 \%$ of the government's total spending. The massive task of promoting quality education is a shared responsibility of two ministries: the Department of Basic Education (DBE) and the Department of Higher Education and Training (DHET). The DBE deals with all schools, from Grade R to Grade 12, and adult literacy programmes and the DHET deals with universities and other post-school education and training institutions and coordinates the Human Resource Development Strategy for South Africa (South Africa, 2013a, p.168).

The South African Schools Act (1996) came into effect on 1 January 1997, with the principal objective of bringing about a uniform system of administration and funding of schools. The education learning programme extended from Grade 0 (better known as Grade R, for "Reception") to Grade 12. This Act provides for compulsory attendance of school for learners between the ages of 7 and 15 (or on the completion of Grade 9). This is known as the mandatory or general education phase. Every provincial Member of the Executive Council (MEC) for Education is legally obliged to allocate a place at a school for every child in the compulsory attendance bracket. If this cannot be done, because of a lack of capacity, the MEC must take urgent steps to remedy the situation (Department of Education, 1996, p.6). Learners from the socio-economically disadvantaged rural communities do not pay school fees (quintile 1-3).

According to Statistics SA (2013, p.3), in a country of approximately 52 million people, 580577 candidates wrote the matric (final) examinations in $2013,61 \%$ of whom passed to obtain the National Senior Certificate. Just over half of the learners achieved a bachelor's pass, making them eligible to apply for university study in South Africa. A bachelor's pass requires, at a minimum, a rating of 4 (or a C) in four subjects from a designated list of subjects. The body responsible for primary and secondary education is the DBE, with 6231 secondary schools, 3821763 learners and 142181 educators (DBE, 2012, p.3). In 2013, the South African government spent $21 \%$ of the national budget on education. Some $10 \%$ of the education budget was for higher education. Total spending on education, in 2011, was $6 \%$ of the gross domestic product (GDP) (World Bank, 2013).

One of the noticeable effects of apartheid was in the area of economic inequality between the different race groups in South Africa (Keswell, 2005, pp.1-2). The difference in income between whites and blacks, before the first general democratic election, was sizeable, with the average salary of whites being more than five times 
that of blacks. Of equal significance was the impact of the apartheid governments social engineering policies specifically regarding race and language that occurred in the field of public education, for instance, the implementation of the Bantu Education Act of 1954, which recommended differential access to education, based on race. Keswell (2005, pp.1-2) acknowledges that the decade after the end of apartheid brought about significant changes in the social and political life of all races, changes which continued in the second decade.

The structural defects of education during the apartheid rule were dealt with in the post-1994 policy outline, which proclaimed fundamental changes. However, numerous challenges continued within the education sector and regarding policy in diverse areas, such as funding and capacity building, both for historically disadvantaged institutions (HDIs) and students, especially those from educationally disadvantaged backgrounds (Odhav, 2009, p.33).

According to the Departments of Basic Education and Higher Education and Training (2011, p.10), the responsibility for educating teachers is the joint responsibility of national and provincial government authorities. It is the statutory duty of provincial colleges to train primary school teachers, while the universities train secondary school teachers. The South African Constitution states that teacher education should fall under central management and control. The national education policy introduced many innovations in the sector to enable quality control appropriate to provincial requirements (DBE, 2010, p.10).

According to the Departments of Basic Education and Higher Education and Training (2011, p.11), there is a scarcity of qualified teachers knowledgeable enough to teach specific subjects or learning areas. Primarily the following subjects were identified: mathematics, the sciences, technology and languages, arts, culture, economic and management sciences, African languages, sign language and Braille. In special needs schools, in the early childhood development sector and, especially, in rural and remote schools, the shortage of teachers is significant.

Teacher development in South Africa is perceived by the Departments of Basic Education and Higher Education and Training (2011, p.13) and many stakeholders as not adequately coordinated and monitored, confusing and burdensome. The Integrated Quality Management System, in particular, is considered to be time-consuming, and it overburdened teachers with the official procedure. Neither teachers nor district officials are adequately trained to manage this official protocol, and the professional training available to teachers is not so relevant as to elevate their performance.

In the South African Millennium Development Goals Country Report $(2005$, p.6), it is indicated that South Africa is on track to meet the millennium development goals. The report shows that the current evaluation of South Africa is as a new middle-income country. The rate of primary school enrolment, since 1995, has remained stable, at about $95.5 \%$, and secondary participation rates are currently approximately $85 \%$, representing an increase of about 15 percentage points since the early 1990s. Also, the male and female enrolment ratio is around $97 \%$, representing a higher overall participation rate. The learner to facility ratio has declined, from 43 to 1, in 1996, to 38 to 1, in 2001, as a consequence of the emphasis on relieving backlogs, indicating that more children are gaining access to classroom facilities than before.

\section{Methodology}

This study employed a qualitative research design, which is guided by the interpretive paradigm because it relies comprehensively on practical methods of content analysis in which concepts are discussed to convey an in-depth understanding of the topic being investigated and bringing new knowledge. This study uses qualitative content analysis as a means of data collection in which existing documents, conference proceedings, journal articles and policy documents on information literacy, in the context of the South African environment, were studied analytically. The researcher embarked on this study to identify whether there is a research gap, which has remained unanswered in previous studies. Key phrases, listed below, were used as a search strategy in selected academic databases, like EBSCOhost, Scopus and Web of Science, and government databases.

This study embarked on a literature review process aimed at addressing issues associated with the use of information in educational development in South Africa. The search strategy was to select key phrases that will unveil new knowledge carefully. In doing this, the study was able to categorise, analyse and integrate the 
findings of scholars and policy documents, from relevant institutions, to address the issues raised in the research. The key phrases selected for this study are as follows:

- Information literacy in South Africa

- South Africa's Bill of Right

- Information access and use in South Africa

- Use of ICT in South Africa

- Cost of internet

- Challenges of information use

- Electricity generation

To achieve this, policy documents from the Departments of Education, Department of Basic Education and Higher Education and Training, and the National Library of South Africa (NLSA), as well as the South Africa Post-Apartheid Higher Education Policy and Marginalisation and South African Millennium Development Goal Country Report, were all included in the study and the relevant portions were evaluated to gauge its efficacy in support of this research endeavour.

\section{Status of information access and use}

After the end of apartheid in 1994, the DBE has been committed to ensuring equal access to education. The introduction of no-fee schools has helped the government to achieve this goal, but this has not translated into quality education (Paton-Ash and Wilmot, 2013, p.127). Even though it has been established that student performance depends on the availability of library facilities, fewer than $8 \%$ of public schools in South Africa have functional libraries (Equal Education, 2011). There is no organised curriculum for computer training and information science literacy; its introduction was a result of the curiosity and enthusiasm of a few teachers in private schools. However, there was a dramatic turnaround when the national Department of Education organised a conference on ICT and education. This, as Boekhorst and Britz observe (2004, p.68), was followed by the Technology Enhanced Learning Investigation (TELI), in 1996. This effort led to an improvement in the broad-based information literacy course that is available in schools, community centres, industry-based training sites and other learning centres. However, in spite of this curriculum development, many schools continue to falter in this regard, due to a lack of adequate power supply, especially in disadvantaged rural areas, and because of insufficient funds to maintain the modern technology (Boekhorst and Britz, 2004, p.68).

Hart and Zinn (2007, p.19) reveal that the introduction of the new school curriculum, in 1996 and then again in 2005 , offered new opportunities, because it encouraged library development in the sense that the capacity to "collect, analyse, organise and critically evaluate information" was identified. The authors further reveal that the new curriculum made provision for adequate resources and accelerated library development. Despite this, it has been reported that, at many schools, libraries are not available for use because of the dual responsibilities of the "librarians", who are both librarians and classroom subject teachers (South Africa, 1997). The extent of the focus of teacher-librarians on library services at schools is not clear. It is, however, clear that $30 \%$ of those who claim to be teacher-librarians simultaneously occupy essential positions such as principals, deputy principals and heads of departments (Hart and Zinn, 2007, p.93). The authors further stress that sources of funding for school libraries are not clear, and it has been established that few schools allocate funds to the library (Hart and Zinn, 2007, p.93). Another limitation to library development in South Africa is the reluctance of the school authorities to recognise the need for school libraries. It is incredible that more than 20 years after the democratic government was ushered in, there is still no school library policy in place. The building and provision of school libraries are not taken seriously because of a lack of strategic planning.

According to the Library and Information Services (LIS) Transformation Charter (National Library of South Africa (NLSA), 2014, p.5), a team was established to eradicate illiteracy and inequality by building an informed and reading nation. Part of the responsibilities of the organisation is to ensure the recognition of information as having the ability to eliminate poverty and empower people because well-informed people are responsible citizens (NSLA, 2014, p.5). Therefore, libraries are expected to play a central role in access to information for all South Africans. Furthermore, the charter emphasises that the South African government and all its developmental partners should actively support the initiative to promote information literacy, develop a modern library and information system and ensure the right of access to information as a fundamental human right for all citizens (NSLA, 2014, p.5). 
Fourie and Krauss (2010, p.303) observe that the information literacy training of teachers in South Africa was funded by UNESCO, with the support of the Departments of Informatics and Information Science of the University of Pretoria. This led to a partnership between the university and some schools, especially those located in the disadvantaged rural areas. Computers were donated to schools to encourage the teachers to acquire information literacy skills. It was also an avenue to test the drafted road map on the Media and Information Literacy (MIL) curriculum. Fourie and Krauss (2011, p.303) note that two training courses for teachers were designed and registered through the Department of Continuing Education at the University of Pretoria. The training programme began in May 2010, with 54 hours' attendance, over nine Saturdays. Even though the UNESCO MIL curriculum was implemented to meet the needs of teachers, as working adults in a developing community, the merits of the training included access to enormous resources of information that can be tailored to any circumstances, enhancing the quality of teaching and learning through the support of international experts (Fourie and Krauss 2011, p.303).

The Bridges to the Future Initiative in South Africa (BFI-SA, 2010), mentioned in the assessment report by USAID on South Africa (2013, p.1), is an initiative to use the power of technology to bring about a positive turnaround in education by designing an interactive, computer-based learning tool to improve literacy levels in schools. The approach was to use the influence of interactive, user-friendly, computer-based instruction and learning methodologies for literacy learning. The BFI-SA (2010) holds that information literacy is an empowerment skill, capable of fostering personal development and community upliftment, and is essential for active participation in the modern world. The report notes that, in spite of this, a low level of literacy is still widespread in South Africa, and the challenge is further complicated by the multicultural and multilingual nature of the country. As a result, an innovative project was designed to enable the use of ICT in local languages and to develop literacy and other learning skills in South Africa (USAID South Africa, 2013). The pilot project was kick-started in Limpopo, with the ambition to replicate its benefits throughout South Africa. BFI-SA is a collaborative multi-agency, coordinated under the sponsorship of the national Department of Education. Multimedia resources and instructional media were carefully designed to aid classroom activities and help the imagination of learners. They were designed in English and other local languages such as Sepedi, Tshivenda and xiTsonga. The project was facilitated through ICT infrastructure, in a blend of adult basic education training (ABET) centres (ABET, 2013). ABET lays the foundation for learning and development in schools, developing skills and attitudes geared toward social, economic and political participation and transformation in secondary schools across the province. Multi-purpose community centres are institutions tasked with the implementation and development of communication and information programmes (Rabali, 2005, p.1). According to BFI-SA (2010), the issue of the digital divide in education and technology was addressed in South Africa as a result of this project by improving literacy, basic education and technological literacy, thereby helping the educators and learners to determine their own social and economic future better. This initiative was promoted, in partnership with public and private organisations and with the support from international agencies and public-spirited foundations, using the tools and techniques of ICT, and adapted to accommodate diverse content and learners.

BFI-SA (2010) reveals that multi-agency collaboration is supported by the national Department of Education, with partnerships that include the National Literacy Institute, the Trydian Interactive and E-learning Development Company and the Molteno Institute of Language and Literacy (MILL), formerly known as the Molteno Project. The MILL is a non-profit organisation that funds literacy programmes and research across Africa from its headquarters in Johannesburg (http://www.molteno.co.za). Trydian Interactive ICT is an innovative organisation, with specialised skills in custom courseware development, deliverable through the web, intranet or cell phone. The organisation is situated in Pretoria, and it is equipped with technology that has a global impact in bringing about a highly accessible and convenient way of learning (http://www.trydian.com/). Chevron, a formidable oil and gas company, in its global energy for learning initiative, has partnered with the Western Cape Department of Basic Education to fund the renovation and restocking of community secondary school libraries, and has also transformed the libraries with modern ICT tools, including computers and various types of audio-visual equipment, aligned with the national school curriculum (http://www.youtube.com/watch?v=uhSMZhfJcck).

In all aspects of ICT development in education, South Africa can boast of decades of projects and programmes embarked upon by communities, the private sector, civil society, donor agencies and government bodies. The wide range of tested models for ICT access, digital content development, teacher training and professional growth, optimal usage, partnerships and resource mobilisation have encouraged significant learning among 
innovators, practitioners and policymakers. This has also led to at least $22 \%$ of computer penetration in South African public schools (Shafika, 2007, p.2). In spite of the improvement in ICT in South Africa, there are still significant challenges confronting this sector. Shafika $(2007$, p.2) holds that harnessing various initiatives to bring about proper management and harmonisation of information literacy in education encourages optimal use of technology to improve investment in ICT to enhance teaching and learning. That will be valuable to learners and increase their chances of employability in a frequently changing labour market. Shafika (2007, p.2) also observes that the policy on ICT in South Africa dates back to 1995, with the emergence of TELI, which in 2001, with the support of the national Department of Education and the Department of Communication, mapped out a strategy for ICT in education, which laid the foundation for e-education. The ambition of this policy was to encourage both primary and secondary sectors to acquire ICT competence by 2013. Shafika $(2007$, p.2) states that to make this vision a certainty, schools were encouraged, through different techniques to develop e-schools, with the support of both teachers and learners.

There is an abundance of evidence that clearly shows that, if efforts are channelled in the right direction, ICT can support teaching and learning accomplishments. However, the introduction of ICT tools and techniques does not automatically improve the quality of education. Therefore, the pedagogical and technical expertise of the teacher is critical. As in most countries, the effort of government has been to focus on teachers' development, as the key to the effective implementation of policy and curricular development, using ICT as a platform for educational development. The current predicament arises from the growing level of poverty, the lack of proper funding and an exponential rise in the student population (Hennessy et al., 2010, p.40).

Internet use has become relatively common in many secondary schools in South Africa, but there are still challenges in some areas (Matlala, 2015, p.8), mainly in disadvantaged rural communities. However, the challenges of internet connectivity, online library resources, computer facilities, computer literacy training and relevant instructional software are familiar in urban areas as well.

\subsection{Policy framework}

In recognition of the value of access to information in South African society, section 32(1) of the Constitution of 1996 affirms that access to information is the fundamental right of every citizen, whether the information is in the custody of the state, the corporate sector or individuals, as long as it will uphold a culture of transparency, responsibility and accountability in the private and public sectors as against the strict confidentiality and official procedure that will not foster a culture of openness, and can impede access to information. South Africa is the first country in Africa to recognise the importance of access to information in the Constitution. Given this, it can be inferred that the Constitution of South Africa realises the importance of information to the education and development of our citizens and, therefore, to deprive anybody of it, is against the letter and spirit of the law.

Numerous policy frameworks have been put in place in South Africa to promote information use, for instance, the Presidential National Commission on Information, Society and Development Two advisory bodies have been set up to help the President form an opinion on matters that have to do with the development of an inclusive information society. According to the Department of Public Service and Administration of South Africa $(2012$, p.1), the government put in place a policy framework to ensure the mutual control and governance of ICT as an essential division of corporate governance within departments in a standardised and coordinated manner. The agenda offers a set of central beliefs and processes to which all government departments must conform.

The national Department of Education has developed guidelines to enable teachers to use ICT in classroom instruction. Currently, a few programs have been designed to help teachers develop ICT skills in South Africa, programs such as SchoolNet South Africa, Educators' Development Network and Microsoft Partners in Learning (Shafika, 2007, p.16).

The broadband policy, tagged "South Africa Connect", contains details of activities to improve broadband in South Africa, improve access to the broadband connection at a reduced cost of $2.5 \%$ or less of the average monthly income and also increase the speed of broadband. The Independent Communication Authority of South Africa (ICASA, 2018), the regulatory body for the South African communications, broadcasting and postal services sector, was established to complement the ambition of improved broadband identifying standards, download and upload speeds, latency, waiting time for installation and fault clearance . 


\subsection{Human resources development}

Teachers are significant participants in curriculum delivery in any educational environment, and they help to elicit outstanding performances from learners. Nevertheless, there is a general shortage of human resources. The vacancy rate, by January 2012 , averaged $8.7 \%, 10.2 \%$ and $8.7 \%$ for principals, heads of department and teachers, respectively. In 2008, 5942 new teachers graduated from various institutions in the country, representing a $74.5 \%$ increase in four years. Based on this estimation, a considerable improvement was expected in the next two years, and by 2014, over 14000 new teachers were expected to join the workforce (South Africa, 2013a). In 2013, there were approximately 25000 public schools and 391708 educators (South African info, 2015).

The population of newly qualified teachers is decreasing. Personal payroll data indicates that approximately 10100 teachers in public schools leave the profession annually, but approximately 5000 recently-qualified teachers have been joining each year (DBE, 2011, p.100).

Access to ICT resources in South African schools has enjoyed steady improvement over the years. By 2007, more than $80 \%$ of school principals and $60 \%$ of teachers reportedly had access to a computer system at school. By $2009,23 \%$ of schools had a computer centre, though this figure varies according to the province, from the highest in the Western Cape, of $60 \%$, to $10 \%$ in the Eastern Cape (Department of Education, 2011, p.92). The evidence reveals that teachers have access to the internet in their various schools. According to the Census, school, access to the internet at home, by learners, doubled from $9 \%$ to $20 \%$ between 2001 and 2009. But there is an indication, based on statistics, that the internet remains more popular among the privileged few in society (Department of Education, 2011, p.93).

\subsection{Finance}

Expenditure on basic education, in 2015-16, was approximately R203 468 billion. Over the next three years, nearly R640 billion is expected to be spent on basic education (Davis, 2015). Since November 2007, the Department of Education in South Africa has collaborated with corporate organisations in subsidising education for students to the level of R40 a month. In view of this, the Fundisa Fund organised a three-pilot project fund, designed to financially assist students, on merit, in view of the fact that the Department of Education made available R9.2 billion, as an intervention fund, and, at the same time, the National Student Financial Aid Scheme committed the sum of R21 million (South African info, 2015). The South African Democracy Education Trust, established as a trust fund in honour of former South African President Thabo Mbeki, is an initiative supported and funded by MTN, the Nedbank Group and the National Lottery Distribution Trust Fund.

\subsection{Facilities and equipment}

In November 2013, the Ministry of Basic Education published lawfully obligatory Norms and Standards for Public School Infrastructure, amending the South African Schools Act 84 of 1996, to regulate issues relating to minimum uniform rules and standards expected of public-school infrastructure. This Act recommended, among other things, the minimum space in a school that should be apportioned to each learner and educator, an electricity supply that conforms to the appropriate law that serves the school's requirements, a water supply that must meet personal and hygienic conditions and efficient sanitation facilities. It is mandatory for all schools to have a library or a media centre appropriate for the school, laboratories must be available for science, technology and life sciences, sport and recreation facilities should be available to ensure the physical and mental development of learners, electronic connectivity must include internet facilities, a fax machine, telephone facilities and intercom, and above all the facilities must be subject to upgrading to meet the prevailing circumstances (Department of Education, 1996).

There has been a rapid growth in the number of schools with computers and other instructional media for teaching and learning in South Africa, even though there is a wide gap, comparatively, between provinces in the use of these facilities. Statistics have revealed, according to Angathevar and Mammo (2006, p.202), regional disparities in the growth rate of ICT, with Gauteng, Northern Cape and Western Cape far ahead of other provinces. Computer penetration in South African schools shows that, of the 25582 schools, only $50.9 \%$ have computers and just $22.6 \%$ use computers for teaching and learning (Isaacs, 2007, p.9). 
The Accelerated School Infrastructure Delivery Initiative (ASIDI, 2013) was established by the Department of Education to eliminate backlogs in school infrastructure and to fast-track provision of infrastructural support in South African schools. It is also expected to upgrade the benchmark of schools, to perform at an optimal level, and to get rid of insufficient, risky and inadequate physical infrastructure.

\section{Issues about information access and use in South Africa}

School library and information services are required to make available to learners and teachers an extensive range of information for curricular support, exposing learners to different ideas, knowledge, skills, understanding and opinions. Moreover, the service, according to the DBE (2012, p.3), must inculcate a culture of reading and writing, uphold respect for intellectual property and maintain information literacy skills acquisition to access process and use information resources in different formats, including digital formats, where accessible and suitable. The South African school curriculum is resource-based, to integrate resources to increase information-literate learners and a culture of reading.

Information literacy is the prerogative of a professionally and proficiently qualified school librarian or school media specialist. However, Hoskins (2006, p.59) observes that, in South Africa, of the 23 established universities, only three can educate school librarians, and they are the University of KwaZulu-Natal, the University of Zululand and the University of the Western Cape. The qualification at the end of the three years' training is referred to as the Advanced Certificate in Education (ACE) (School Library Development and Management) in KwaZulu-Natal, and the ACE (School Librarianship) in the Western Cape (Zinn, 2012, p.89). As a result of the significant shortfall in the number of school librarians, many secondary schools have suffered a major setback. For instance, fewer than $8 \%$ of South African public schools have efficient and well-designed libraries, and there is no policy framework to coerce school governing bodies and principals to establish libraries (Paton-Ash, 2012, p.ii).

\section{Challenges and opportunities associated with information access and use}

South Africa is one of the countries struggling with problems related to the digital divide, a result of the inability of many to access ICT tools capable of enhancing their performance. Naidoo and Raju (2012, pp.33-44) note that the Department of Education has set up the Extended Curriculum Programme, explicitly designed to aid academic activities, by developing independent learning skills, which are at the heart of information literacy. This is necessary, particularly in a racially divided country such as South Africa, where a separate educational development policy was pursued during the apartheid era, which, in spite of government efforts to bring about change, is still noticeable, because learners from educationally disadvantaged environments continue to struggle with the use of modern technology, especially with instructional media and web facilities that have been incorporated into the school system. Given this, the possibility of learners achieving total information literacy will depend mainly on their educational background.

De Jager and Nassimbeni (2002, p.168) concur with the view that many students gain admission to higher education institutions without prior knowledge of the use of a library and other modern information resources. Information literacy training is therefore of paramount importance, even though trainers are warned to be mindful of the fact that many students are not equally exposed to the skills at an early stage. They should, therefore, strive to bridge the digital divide by introducing intervention programmes to assist such students. Fourie and Krauss (2010) suggest that information communication technology for development, otherwise known as ICT for development, or ICT4D, may be the catalyst for teachers' information literacy empowerment.

Boekhorst and Britz (2003, p.64) acknowledge that modern society must be acquainted with information and ICT skills, even though knowledge is partly learnt in daily activities. For it to enable efficient learning, it ought to be part of the school curriculum. Initially, in South Africa, there was no curriculum for computer education and information literacy.

Fourie and Krooden (1999, p.3) explain that the University of South Africa, the Bureau for University Teaching and the Centre for Software Engineering were all involved in the development of a module, namely Research Information Skills. This module was given a test run on a selected number of students, many of whom expressed anxiety about their inadequate knowledge of computer and library skills. This shows that the lack of experience in using information technology will impede learners' ability to master research information skills. 
The impact of the apartheid era has been identified by Fourie (2008) as a significant reason why ICT does not enjoy equitable access in South Africa. In consequence, the government implemented the Accelerated and Shared Growth Initiative of South Africa (ASGISA), because of the realisation that modern technology is a catalyst for improvement in education, which can boost productivity and efficiency and reduce unemployment.

\subsection{Cost of getting the internet}

There has been significant growth in internet penetration in South Africa, but the major challenge is that only a fifth of the population enjoys internet access. The internet is not affordable, because ADSL is priced beyond the reach of many in South Africa. Buying a large data bundle costs substantially less per megabyte than a small data bundle (Wild, 2013).

\subsection{Speed and time-consuming internet}

Cost, inadequate access and slow connectivity of the internet impede economic growth and job creation in a contemporary economy. In South Africa, average internet connection speeds are low, but are among the highest in Africa (Hampton, 2013), at $4.90 \mathrm{mbps}$ (Net index, 2013), which is inadequate for timely access to information.

\subsection{ICT infrastructure}

The Global Information Technology Report (2013) reveals that South Africa performs comparatively well in ICT infrastructure, based on the survey in the Networked Readiness Index, but its rank is dragged down by digital content inaccessibility. The assessment was based on electricity production ( $\mathrm{kWh} / \mathrm{capita}$ ), mobile network coverage, international internet bandwidth (kb/s per user) and secure internet servers (per million users in population).

\subsection{Electricity generation}

None of the modern information access devices can function without adequate electricity supply. South Africa supplies two-thirds of Africa's electricity and is ranked as the fourth cheapest electricity producer in the world. Almost $90 \%$ of South Africa's electricity is generated in coal-fired power stations; other sources are nuclear energy, hydro-electric power and pumped storage schemes. Eskom is the company responsible for electricity generation in South Africa (http://www.energy.gov.za/files/electricity frame.html).

The opportunity for information access has become brighter in South Africa, especially for teachers, whose profession depends solely on up-to-date information. Statistics about South African households (Statistics SA 2014, p.13) reveal that $40.9 \%$ of households have a minimum of one person with access to the internet at their home, workplace or somewhere else, $10 \%$ of the households now have internet access, and $30 \%$ of people access the internet from their workplace $(16 \%)$, schools $(5.1 \%)$ or at numerous cyber cafés $(9.6 \%)$. Predictably, more homes in the metropolis enjoy internet access $(16.4 \%)$, in contrast to the rural areas $(2 \%)$ and urban centres (9.2\%). The window of opportunity for information access by rural dwellers is offered by the broad coverage of telecommunication facilities, which allows them to use mobile devices to access the internet (17.9\%). The percentage of South Africans using cellphones to access information is $30.8 \%$ of the total population of $81.9 \%$, who have access to cellphones. These new statistics reveal a marginal increase in internet usage in South Africa compared to previous years.

\section{Conclusion}

Information has been described by Elliot (2007) as the fifth factor of production, the use of which can lead to the development and improvement of other factors. Many countries have put policies and measures in place to ensure that citizens have access to quality information, as this will enable the workforce to accelerate economic development and give the country a competitive advantage in the community of nations.

The post-apartheid government of South African has stressed the need to make education and information available to previously disadvantaged communities. It has, therefore, expanded the geographical scope of learning to capture those outside the range of quality education and access to information, which is considered a prerequisite in the endeavour to bridge the gap of inequality that currently exists. Consequently, a considerable amount of time, energy, resources and partnerships with donor agencies have been diverted to achieve this ambitious scheme. Regardless of these efforts, much is yet to be achieved, especially regarding 
the imbalances that exist in accessing technology, which is a key driver in contemporary education systems, and the obstacles that hinder the dissemination and implementation of media and information literacy in South Africa. Other areas of change that need urgent attention are the absence of qualified teachers, most notably in the rural areas, training for the instructors, and the non-implementation of IT literacy in the curricula as a result of insufficient human resources, all of which are indispensable fundamentals for imminent development. Addressing these challenges can help to close the gap in the digital divide and assist in stimulating social inclusion.

The difficulties associated with the digital divide and the resultant social and economic challenges are vastly prevalent in South African society today, for instance, access to ICT facilities, especially the internet, is not universally available, and, therefore, it is mainly to the previously disadvantaged majority that is deprived of access, while a minority does have access. This places them in a favourable position since access to information will empower them to take advantage of the potential of the country and be part of the engine of growth. To bridge the gap of the digital divide in South Africa, the difficulty in accessing the internet must be addressed, and equal prominence must be given to the information literacy programme.

Information is fundamental to the progress and development of any nation. From time immemorial, the availability of information has always played a significant role in the development of nations. An ill-informed citizen will not be able to hold government accountable for their actions; thus, democratic principles can be violated in a community of uninformed people. If information is readily accessible to people, the level of transparency will increase, and many of the socio-political challenges of a country can be resolved. The law establishing freedom of information in the developing countries of Africa varies from country to country, with different levels of application. The government of Nigeria passed into law the Freedom of Information (FOI) Act to increase people's access to information. But, even though the FOI Act is now law in Nigeria, the political will to give effect to it is lacking. Many states of the federation have yet to adopt the Act; thus, access to relevant information from the government is difficult. Restricted access to public information has aggravated corruption, which is one of the reasons for the decline in education, which has had a ripple effect on library development.

Information literacy was accommodated in the post- apartheid curriculum of 2005 as crucial to South African education in which capacity to use information resources well will give the country a competitive edge. Regardless of the increase in the government's budgetary allocation to Education yet there is consensus that apartheid legacy still continues, because many people are still caught in the problem associated to digital divide. There is constitutional provision in South Africa to guarantee to enable everyone equal access to information, irrespective of this constitutional provision, there restriction to certain information by state security to cover up information of public interest.

In South Africa, a similar law also enables people to seek and obtain information from private organisations, especially those that offer public services and enjoy government funding. Information from various sources can help to reduce illiteracy. A country with a high degree of literacy can participate more effectively in economic development and is capable of self-development, which is a prerequisite for human progress. A country that sets up a platform to reduce ignorance will enable literacy to develop and combat various societal challenges. Information-literate citizens can maximise a country's potential and turn limitations to opportunities.

On the other hand, poverty remains a common phenomenon in an environment where illiteracy dominates. Information literacy is related to political literacy, which is the level of citizens' awareness of their rights, duties and responsibilities that empower them to take the right decisions. People, who are not well informed, may lack the ability to vote for leaders that will represent their interests and promote national integration and cohesion. Political literacy can be considered as a skill essential to empower citizens to participate effectively in the act of governance, which includes a better understanding of government policy and its effect on larger society, and to enhance citizens' ability to form independent political opinions.

\section{References}

ABET, 2013. Adult basic education and training: Supporting adult learning in South Africa. Available at: Adult Basic Education and Training website $<$ http://www.abet.co.za/> [Accessed 20 July 2019 
Accelerated School Infrastructure Delivery Initiative. (ASIDI) 2013. Accelerated schools' infrastructure delivery initiative. Available at: Development Bank of Southern Africa <https://www.dbsa.org/EN/AboutUs/Projects/Pages/Accelerated-Schools-Infrastructure.aspx $\geq$ [Accessed 21 July 2019]

Angathevar, B. and Mammo, M., 2006. Bridging the Digital Divide. London: Adonis \& Abbey.

Association of College \& Research Libraries (ACRL)., 2016. Framework for information literacy for higher education. Journal of Information Literacy, Vol. 13(1). Available at: Association of College and Research Libraries <http://www.ala.org/acrl/sites/ala.org.acrl/files/content/issues/infolit/Framework ILHE.pdf.> [Asseesed 27 July 2019]

Banciu, D. R., Petre, I. R. And Boncea, R., 2019. 'Information and Documentation through New Technologies in E-Learning Process', eLearning \& Software for Education, 2, pp. 465-470. doi: 10.12753/2066-026X-19-134.

Boekhorst, A.K and Britz, J.J., 2004. Information literacy at school level: A comparative study between the Netherlands and South Africa. South Africa Journal of Libraries and Information Science. 70 (2) : pp.63-71

CILIP. (2018). CILIP definition of information literacy 2018. Available at: <https://infolit.org.uk/ILdefinitionCILIP2018.pdf> [Accessed 27 July 2019]

Davis, R., 2015. Budget 2015: Where's the money at? Available at: <https://www.dailymaverick.co.za/article/2015-02-26budget-2015-wheres-the-money-at/> [Accessed 20 July 2019].

De Jager, K. and Nassimbeni, M., 2002. Institutionalizing information literacy in tertiary education: Lessons learned from South African programmes. Library Trends. 51(2): pp.167-184.

Department of Basic Education., 2011. Action Plan to 2014: Towards the Realisation of Schooling 2025. Available at: <https://www.gov.za/sites/default/files/gcis_document/201409/dobeshortened-action-plan-2025031120100.pdf> [Accessed 24 July 2019].

Department of Basic Education., 2012. National Guidelines for School Library and Information Services. Available at: : <http://www.education.gov.za/LinkClick.aspx?fileticket=D1G\%2Bh5KkVkw\%3D\&ta bid=93\&mid=1952>[Accessed 25 July 2019].

Department of Education., 1996. South African Schools Act 84 of 1996 1996: National Norms and Standards for School Funding. Available at:

<https://www.sacplan.org.za/documents/NationalMinimumNormsandStandardsforSchoollnfrastructureDepartment ofEducation.pdf $>$ [Accessed 23 July 2019].

Department of Education., 2010. Education Management Information System (EMIS). Available at <http://www.kzneducation.gov.za/Directorates/EMIS.aspx> [Accessed 25 July 2019].

Departments of Basic Education and Higher Education and Training., 2012. Annual Report. Available at: <http://www.dhet.gov.za/Commissions\%20Reports/Annual\%20Report\%202011\%20-\%202012.pdf> [Accessed 26 July 2019].

Department of Basic Education., 2011. Action Plan to 2014: Towards the Realisation of Schooling 2025. Available at: https://www.gov.za/sites/default/files/gcis document/201409/dobeshortened-action-plan-2025031120100.pdf [Accessed 26 July 2019].

Department of Education, KwaZulu-Natal, 2014. Available at: <http://www.kzneducation.gov.za/Directorates/EducationLibrarylnformationTechnologyService.aspx> [Accessed 26 July 2019]

Department of Public Service and Administration of South Africa, 2012. Public Service Corporate Governance of Information and Communication Technology Policy Framework. Available at $<$ http://www.dpsa.gov.za/dpsa2g/documents/psictm/2013/CGICT\%20Policy\%20Framework.pdf> [Accessed 24 July 2019].

Durodolu, O. O (2019). Multilateral relationship between Information Literacy, Self-concept and Metacognitive ability. In Metacognition in Learning. (in publication).

Elliott, T., 2007. BI is Deploying Information as a Factor of Production. Available at: <http://timoelliott.com/blog/2007/09/bi is deploying information as.html> [Accessed 24 July 2019].

Equal Education, 2011. Ten years of youth activism. Availble at: <https://equaleducation.org.za/> [Accessed 25 July 2019 ].

Fourie, L., 2008. Enhancing the livelihoods of the rural poor through ICT: A knowledge map (South Africa Country Report). Available at <https://www.datafirst.uct.ac.za/dataportal/index.php/citations/2999> [Accessed 27 July 2019].

Fourie, I. and Krauss, K., 2010. Information literacy training for teachers in a developing South African context: Suggestions for a multi-disciplinary planning approach. Innovation, No. 41, Vol. 41 (1) pp. 107-122.

Fourie, I. and Krooden, E., 1999. Providing learning opportunities for teaching research information skills, Progression. 21(2), pp. 1-14. Available at <http://uir.unisa.ac.za/bitstream/handle/10500/115/progress v21 n2 a7.pdf?sequence=1> [Accessed 22 July 2019].

Global Information Technology Report., 2013. Growth and jobs in a hyper connected world. Available at: <http://www3.weforum.org/docs/WEF GITR Report 2013.pdf> [Accessed 22 July 2019].

Hampton, M., 2013. The damn slow speed of South Africa's internet services. Available at <http://www.knysnawebsitedesign.co.za/the-damn-slow-speed-of-south-africas-internet-services/> [Accessed 22 July 2019].

Hart, G. and Zinn, S., 2007. The Conundrum of School Libraries in South Africa. Available at: $<$ www.dissanet.com/ifla/pdf/LIASA\%2007\%20Hart\%20\&\%20Zinn.pdf > [Accessed 22 July 2019]. 
Hennessy, S., Harrison, D. London, E. and Wamakote, L., 2010. Teacher factors influencing classroom use of ICT in Subsaharan Africa. Available at: < http://citeseerx.ist.psu.edu/viewdoc/summary?doi=10.1.1.461.916> [Accessed 22 July 2019].

Hoskins, R., 2006. Libraries and teacher-librarians in KwaZulu-Natal. Innovation: Journal of Appropriate Librarianship and Information Work in Southern Africa, No.33, pp. 59-75.

Independent Communication Authority of South Africa (2018). Regulating the Communications Sector in the Public Interest. Available at: <https://www.icasa.org.za/> [Accessed 28 July 2019]

Isaacs, S., 2007. Survey of ICT and education in Africa: South Africa country report South Africa - 1: ICT in education in South Africa. Available at <http://www.infodev.org/infodev-files/resource/InfodevDocuments 429.pdf $>$ [Accessed 22 July 2019].

Keswell, M., 2005. Education and racial inequality in post-apartheid South Africa..Available at: $<$ file:///C:/Users/USER/Downloads/education and racewd.pdf> [Accessed 22 July 2019].

Matlala, M. E., 2015. The use of the Internet by grade 11 learners from selected schools in the Sekhukhune district, Makhuduthamaga local municipality in Limpopo Province. Natal, South Africa: University of KwaZulu.-

Naidoo, S. and Raju, J., 2012. Impact of the digital divide on information literacy training in a higher education context. South Africa Journal of Libraries and Information Science, Vol.78 (1). pp. 34-44

National Library of South Africa (NLSA)., 2014. Library and Information Services (LIS) transformation charter. Available at <http://www.liasa-new.org.za/wp-content/uploads/2016/02/LIS-Transformation-Charter-Priorities.pdf > [Accessed 24 July 2019].

Net index., 2013. Household download index. Available at: <http://www.netindex.com/download/allcountries/> [Accessed 22 July 2019].

Odhav, K., (2009) South African post-apartheid Higher Education policy and its marginalisations: 1994- 2002. South Africa Education Journal, Vol. 6(1), pp.33-57.

Paton-Ash, M. and Wilmot, D., 2013. The state of school libraries in South Africa. Journal of Education, No. 57. pp. 127-162

Rabali, H., 2005. The role of multi-purpose community centre (MPCC) service and information providers towards improving the quality of community life: A case of Sebokeng. Avaialble at <http://dspace.nwu.ac.za/handle/10394/985> [Accessed 25 July 2019].

Shafika, I. (2007). Survey of ICT and education in Africa: South Africa country report, ICT in education in South Africa. Available at <http://www.infodev.org/infodev-files/resource/InfodevDocuments 429.pdf>[Accessed 22 July 2019].

Scottish information literacy project (2013). literacy across learning: information and critical literacy skills CPD for early and first level. The right information: information skill for a 21st century Scotland. Available at $<$ http://www.therightinformation.org/realrelevant-importanceof/> [Accessed 23 July 2019].

Solomon, A. Wilson, G. and Taylor, T., (2012). 100\% information literacy success. 2nd ed.; Wadsworth Cengage learning. Available at: <http://45pi.com/ebook/100\%25\%20Information\%20Literacy\%20Success-\%202\%20Edition.pdf> [Accessed 28 July 20]

South Africa Millennium Development Goals Country Report., (2005). Millennium development goals, targets and indicators. Available at: <https://www.unicef.org/statistics/index 24304.html $>$ [Accessed 23 July 2019].

South Africa., (1997). A national policy framework for school library standards: A discussion document. Unpublished report. Directorate: Centre for Educational Technology and Distance Education. Pretoria: Department of Education.

South Africa., (2013a). South Africa Yearbook 2012/13. Available at: <https://www.gcis.gov.za/content/resourcecentre/sainfo/yearbook2012-13> [Accessed 22 July 2019].

South Africa., (2013b). Statistical release: Mid-year population estimates. Available at: $<$ http://beta2.statssa.gov.za/publications/P0302/P03022013.pdf > AAccessed 28 July 2019\}

South African info, (2015). Brand of South Africa's information gateway to South Africa: Fund makes education affordable. Integrated Marketing. Available at: $<$ https://www.brandsouthafrica.com/investmentsimmigration/africanews/education-in-south-africa> [Accessed 25 July 2019].

Statistics South Africa, (2014.) General household survey. Pretoria; Statistics South Africa Available at: <http://beta2.statssa.gov.za/publications/P0318/P03182013.pdf [Accessed 22 July 2019].

USAID South Africa., 2013. Fact Sheet Bridges to the Future Initiative in South Africa. Available at <https://uil.unesco.org/case-study/effective-practices-database-litbase-0/bridges-future-initiative-south-africa> [Accessed 22 July 2019].

Wild, S., 2013. Cutting to the price of internet access in SA: Internet penetration in South Africa remains sluggish due to the high cost of connectivity. Available at: $<$ http://mybroadband.co.za/news/broadband/84575-cutting-to-the-price-ofinternetaccess-in-sa.html : [Accessed 27 July 2019].

World Bank., 2012. International human development indicator. Available at: <https://www.worldbank.org/en/country/southafrica> [Accessed 24 July 2019]. 